\title{
Postharvest Quality and Safety of Fresh-Cut Melon Fruits Coated with Water Soluble Chitosan Films
}

\section{G. ZSIVANOVITS ${ }^{1}$, TS. GRANCHAROVA ${ }^{2}$, I. DIMITROVA-DYULGEROVA ${ }^{3}$, D. IVANOVA ${ }^{3}$, S. KOSTADINOVA ${ }^{3}$, M. MARUDOVA ${ }^{2 *}$}

\begin{abstract}
The research presents the effect of novel edible coatings based on low molecular weight chitosan on some properties of fresh-cut melon fruits - weight loss, total soluble solids, total acidity, mechanical strength and bacteria growth. Three different compositions were used as coatings - pure chitosan, chitosan and Ca lactate and alginate/chitosan multilayers. It was shown that the additional alginate layer substantially improves the protective properties of pure chitosan coating, resulting in preservation of cell structure. Negligible negative effect on the antibacterial activity of pure chitosan is demonstrated.
\end{abstract}

Keywords: Melo sativus fruits, edible films, chitosan, alginate, cell structure, texture, antibacterial activity, weight loss, sugar/acid ratio

\section{Introduction}

In the recent years a growing interest in fresh-cut fruits and vegetables has been observed, which is mostly due to their advantages such as freshness, low caloric content, commodity to be used and an active promotion of fruits and vegetables as basic components of a healthy diet (Raybaudi-Massilia et al., 2008). As consumers become aware of this importance in their eating habits and have less time for food preparation, the production of fresh-cut fruits is increasingly more relevant from the food processor perspective (Olivas \& Barbosa-Canovas, 2005).

Fresh-cut melons are among the commercially most important fresh-cut fruit products representing about $22 \%$ of the market (Cook, 2014). Melons

\footnotetext{
*Corresponding author. E-mail: margo@uni-plovdiv.bg, marym_99_1999@yahoo. com

${ }^{1}$ Food Research and Development Institute - Plovdiv, Agricultural Academy, Bulgaria

2Plovdiv University "Paisii Hilendarski", Faculty of Physics and Technology, Bulgaria

${ }^{3}$ Plovdiv University "Paisii Hilendarski", Faculty of Biology, Bulgaria
} 
are popular with consumers because of their unique flavor and nutritional value. They are naturally low in fat and sodium, have no cholesterol, and provide many essential nutrients such as potassium, $\beta$-carotene, and vitamin $C$. Melons were recommended as essential diet ingredient to ensure adequate nutrition, promote individual health, and reduce one's risk of chronic diseases. Despite their advantages, minimally processed products are more perishable due to tissue injuries during peeling, slicing, and cutting operations. Wounding of fruit tissue induces a number of physiological reactions that need to be minimized in order to obtain freshcut products with high quality and nutritional value. The wound response results in the increase of respiration rate and ethylene production, which accelerates the senescence process, promoting changes in fruit quality parameters and reducing product shelf life (Soliva-Fortuny \& MartínBelloso, 2003).

One of the most promising methods to increase the shelf-life of freshcut melons is application of edible coatings. Edible coatings protect food products from mechanical, physical, chemical, and microbial damage and can extend their shelf life (Baldwin et al., 2011). They attract much interest and practical research since they are based on natural and edible components that satisfy environmental concerns and respond to customer demands for safe and healthy food (Han \& Gennadios, 2005). To be of practical application, edible coating needs to have strong adhesion abilities, highly effective microbial protection, appropriate gas and moisture exchange properties, a good esthetic appearance, and to be tasteless, all with a reasonable cost.

An interesting biopolymer used in edible coatings is chitosan. Chitosan is a linear polysaccharide consisting of $\beta$ - $(1 \rightarrow 4)$-linked 2-amino-2-deoxy-Dglucose residues, originating from deacetylated derivative of chitin, which is the second most abundant polysaccharide in nature after cellulose (Coma et al., 2002). It is non-toxic, biodegradable, biofunctional, and biocompatible (Coma et al., 2002). Because of its positive charge, chitosan has strong antimicrobial and antifungal activities that could effectively control fruit decay. It possesses very good adhesive abilities and can easily form coating on fruits and vegetables, and the respiration rate of fruits and vegetables was reduced by adjusting the permeability of carbon dioxide and oxygen (Dutta, 2012).

There are already some attempts for the application of chitosan coatings on fresh-cut melons (Poverenov, 2014; Chong, 2015). It was found that the chitosan coatings caused a decrease in the growth of $F$. oxysporum and delayed changes in their external color (Reyhan, 2013). Typically 
chitosan is combined with some other substances like calcium ions to strengthen the fruit cell wall and increase the effect of preservation. Poverenov and coauthor introduced for the first time alginate-chitosan bilayers and demonstrated a great effect in the conservation of fresh-cut melon quality (Poverenov, 2014). Based on our knowledge there are no attempts to use water soluble, low molecular weight chitosan as edible coatings. The aim of the present research is the investigation of the effect of edible coatings based on water-soluble chitosan on the quality of fresh-cut melon fruits.

\section{Material and Methods}

\section{Material}

The fruits of Melo sativus "Honeydew" were bought (30 pieces) from a local marketplace in fully matured stage based on color and outside appearance, without physical and microbiological damages. Fruits were washed with tap water and then manually peeled and cut into $20 \mathrm{~mm}$ cubes. All the utensils used in the processing were previously sanitized with ethanol solution.

\section{Treatment}

Three treatments of edible coatings were done. $1 \mathrm{~g} / 100 \mathrm{ml}$ water soluble low molecular weight chitosan in distilled water $(\mathrm{Ch}) ; 1 \mathrm{~g} / 100 \mathrm{ml}$ water soluble low molecular chitosan ("TIENS Group", China) and 1g/100 ml calcium lactate in distilled water $(\mathrm{Ch}+\mathrm{Ca})$; the third edible coating contained two layers, prepared by $1 \mathrm{~g} / 100 \mathrm{ml}$ solution of sodium alginate in distilled water and $1 \mathrm{~g} / 100 \mathrm{ml}$ solution of water soluble low molecular weight chitosan in distilled water $(\mathrm{Ch}+\mathrm{Al})$. All the solutions were prepared by stirring the polymers with magnetic stirrer overnight until they were completely dissolved.

The fruit cubes were immersed into the solution for two minutes and air dried at room temperature $\left(25^{\circ} \mathrm{C}\right)$ for 30 minutes. After that 10 cubes were placed into plastic containers with punched cups and stored at temperature $4 \pm 1^{\circ} \mathrm{C}$. Twenty containers were filled from each treatment.

The layer-by-layer polyelectrolyte deposition process was used to prepare double-layer coating. First the melon cubes were dipped into alginate solution for two minutes, then they were dried at room 
temperature for 60 minutes, and finally were immersed in chitosan solution for another two minutes. After second drying the fruits were packed into plastic containers and stored at $4 \pm 1{ }^{\circ} \mathrm{C}$ and relative humidity $\mathrm{RH}=60 \pm 5 \%$ ). These settings were controlled by datalogger (EasyLog EL-USB-1, Lascar Electronics, UK) with one reading per minute.

\section{Fruit quality}

Ten melon cubes were weighed after the processing (day 1) and along storage (at days 5, 8, 11, 15 and 18). The results were expressed as percentage loss of initial weight.

The $\mathrm{pH}$ of the homogenized samples was determined by Microsyst MS2011 portable pH-meter (Microsyst, Bulgaria), with temperature compensator.

Total acidity (TA) was examined by titration with $\mathrm{NaOH}(0.1 \mathrm{n})$ added into the juice/water solution towards the end point $\mathrm{pH} 8.1$ (equ. 1). The result is expressed in $\mathrm{g} / \mathrm{l}$ : (OECD Standards, 2005)

$$
\frac{g}{l} \text { acid }=\frac{\text { Titre } \cdot \text { Acid factor } \cdot 100 \cdot 10}{10(\text { ml juice })}
$$

Soluble solid content (Brix\%) of the samples were measured by an Abbe refractometer (Abbe- 2WAJ, UK) with temperature correction. For further analysis the sugar/acid ratio (equ. 2) was calculated (OECD Standards, 2005):

$$
\frac{\text { Sugar }}{\text { acid }} \text { ratio }=\frac{\text { Brix } \cdot 10}{\frac{g}{l} \text { acid }}
$$

The fruits flesh elastic modulus was measured by a universal testing machine (TA-XT2 plus texture analyzer, Stable Micro Systems, UK). The slope of the stress-deformation curve was obtained by moving a cylindrical probe $(25 \mathrm{~mm})$ at low deformation speed of $0.1 \mathrm{~mm} / \mathrm{s}$.

The structural changes of melon tissue were evaluated through light microscopy analysis at days 1, 5, 8, and 14. Duplicates were examined using a light microscope Magnum T, trinokular, with camera Si 3000, 3 megapixel USB (Medline Scientific, UK). 


\section{Microbiologycal analysis}

Samples were analyzed with respect to aerobic bacteria, yeast and mold growth, coliforms, Escherichia coli and Salmonella spp. viable counts were expressed as colony-forming units (CFU) per gram of fruits. The samples were serially diluted in $0.9 \% \mathrm{NaCl}$ and aerobic plate counts were determined by surface inoculation of plate count agar (Oxoid, UK). The plates were incubated at $30^{\circ} \mathrm{C}$ for $48 \mathrm{~h}$. Mold and yeast counts were determined by surface inoculation of Sabouraudo dextrose agar supplemented with chloramphenicol (Oxoid, UK). The plates were incubated at $25^{\circ} \mathrm{C}$ for 5 days. Total coliforms and E. coli were determined according to ISO 4832:2006 and ISO 16649:2001. Salmonella spp were determined according to ISO 6579:2002.

\section{Statistical analysis}

The results were statistically evaluated by analysis of variance, using the software Statgraph, in order to determine significant differences among the samples. Mean separation was performed with the Multiple Range Test at $\mathrm{p}$ $\leq 0.05$.

\section{Results and Discussion}

\section{Weight loss}

The decrease of weight is predominantly due to water loss that resulted from surface water evaporation respiration and transpiration. No substantial differences could be observed in the non-treated and treated samples up to $8^{\text {th }}$ day of storage. At the end of storage period (after the $15^{\text {th }}$ day) samples, coated with $\mathrm{Ch}+\mathrm{Ca}$ lactate and multilayers from $\mathrm{Ch}+\mathrm{Al}$, show slower increase of the weight loss, Ca salts maintaining the strength of the cell wall due to formation of ionic binding between the Ca cations and pectin from the cell wall (Ferrary et al. 2013). The Ch + Al interact to form water insoluble polyelectrolyte complexes (Tapia, 2004). The cross-linked pectin network or insoluble coating delays the process of water evaporation and reduces the weight loss. (Fig. 1) 


\section{Total soluble solids (BRIX)}

Brix values of all the samples increased during storage period because of the sugar concentration raised due to dehydration observed during storage.

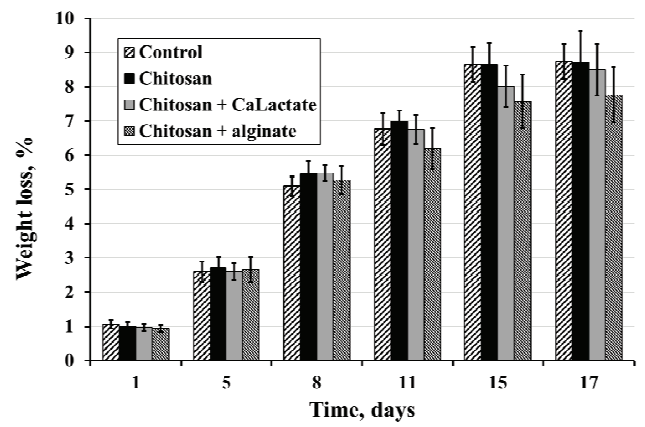

Fig. 1. Weight loss of fresh-cut melon during storage at $4{ }^{\circ} \mathrm{C}$

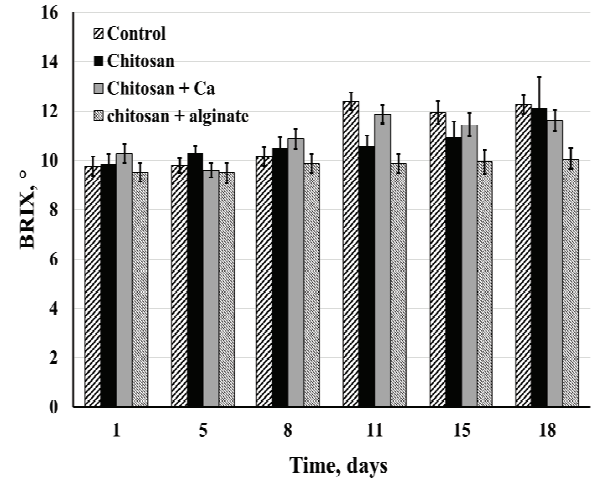

Fig. 2. BRIX of fresh-cut melon cubes during storage at $4{ }^{\circ} \mathrm{C}$

The control presented the highest Brix values and $\mathrm{Ch}+\mathrm{Al}$ the lowest. The coating led to a lower increase in the Brix, which indicates that the control fruit presented a more obvious ripening development than the coated melons, and this could be related to the higher respiration rate observed in the uncoated samples. In addition, the process of coating could modify the internal atmosphere, showing similar effects to fresh-cut melons under modified atmosphere packaging conditions. (Fig. 2) These results agree with the findings of Martinez-Romero et al. (2006), and Aday and Caner (2010).

\section{Total acidity (TA) and sugar/acidity ratio}

TA decreased during the storage period for all investigated samples (Fig. 3). TA of the coated melon cubes was always higher than the average TA of the uncoated ones. The TA of melons coated with $\mathrm{Ch}$ and $\mathrm{Ch}+\mathrm{Al}$ was significantly higher than that of non-treated samples and those coated with $\mathrm{Ch}+\mathrm{Ca}$. No statistical differences were determined between the values of TA during the storage period for all coated samples. Therefore, it could be assumed that the edible coatings act as a barrier and reduce the use of organic acids in respiration and mass transfer. 
Figure 4 shows the sugar/acidity ratio plotted as a function of storage time for the coated and uncoated samples. During the storage sugar content increased while TA decreased, resulting in an increase in sugar/acidity ratio.

\section{Mechanical strength}

The strength (Fig. 5) of the fresh-cut melon was characterized based on the values of normalized (based on the value for the first day) elastic modulus during compression test.

During the 18 days of storage, the elastic modulus of non-treated samples decreased dramatically to $40 \%$ of its initial value. Very similar are the results in case of pure Ch coating - the elastic modulus on the $18^{\text {th }}$ day is only $42 \%$ from the initial. This observation could be associated with the highest weight loss of the non-coated and chitosan-coated samples (Zsom et al, 2016). Therefore, it could be concluded that after the $15^{\text {th }}$ day of storage Ch coating had no more beneficial effect on product texture. Considerably higher are the moduli in case of coatings $\mathrm{Ch}+\mathrm{Ca}$ and $\mathrm{Ch}+\mathrm{Al}-53$ and $73 \%$, respectively. Our results are in good agreement with previously reported data, based on which edible coatings physically enhance the structure of fresh-cut fruits and slow down their texture degradation (Baldwin et al., 2011). They also confirm the synergistic effect of chitosan/alginate multilayers, observed by Poverenov et al (2014).

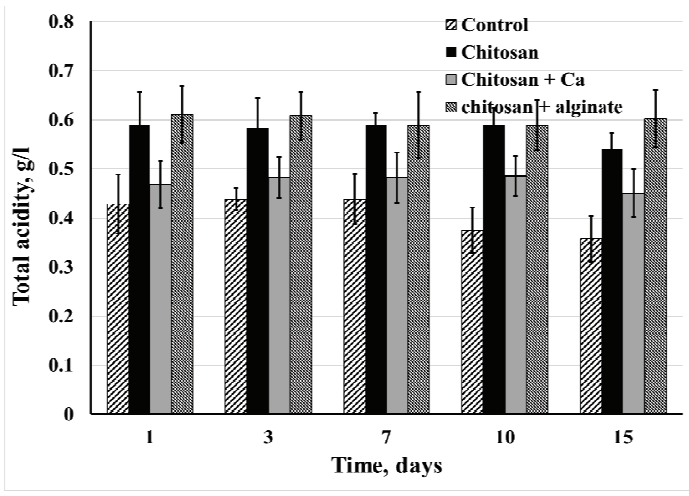

Fig. 3. Total acidity of fresh-cut melon cubes during storage at $4{ }^{\circ} \mathrm{C}$

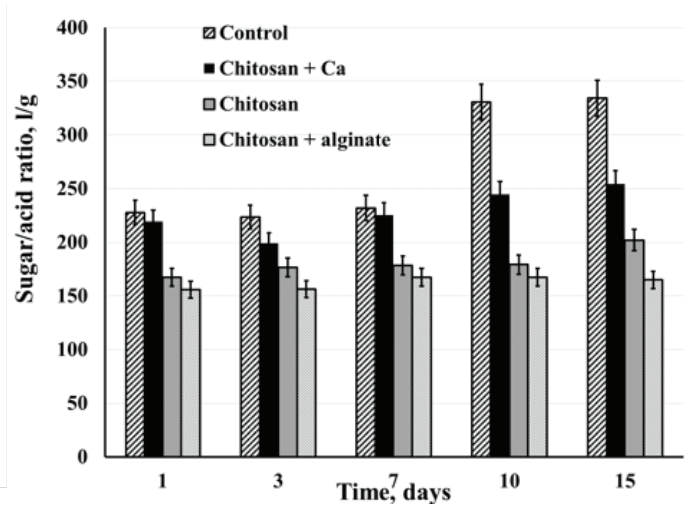

Fig. 4. Sugar/acid ratio of fresh-cut melon cubes during storage at $4{ }^{\circ} \mathrm{C}$ 
The bacteriostatic effect of $\mathrm{Ch}$ based films could inhibit the production of microbial hydrolytic enzymes affecting the cell wall integrity of fresh-cut products (Chen et al., 2002). During the storage enzymatic hydrolysis of cell wall pectic substances and the action of pectinolytic enzymes decrease the cellulose crystallinity and the thinning of cell walls.

The cross-linking of Ca ions from the coating with the pectin in the cell wall delays the process of cell wall degradation and therefore the $\mathrm{Ch}+\mathrm{Ca}$ coatings retain the texture for a longer time (Qi, 2011). The best texture preservation is demonstrated from $\mathrm{Ch}+\mathrm{Al}$ multilayers. One of the reasons for that might be that the combined LbL coating had advantages of both coating materials when internal $\mathrm{Al}$ layer provided perfect adhesion and the external $\mathrm{Ch}$ layer mitigated structure degradation caused by microbial enzymes (Poverenov, 2014) or formation of hydrophobic polyelectrolyte complex, which delay the degeneration processes in the fruits.

\section{Microscopic investigation}

Further investigations of structural changes of fresh-cut melon cubes have been made by the use of microscopic measurement (Fig. 6) At the $1^{\text {st }}$ day, all the samples showed similar characteristics, that is, turgid and round-shaped cells with a well-defined and thin cell wall. At the $8^{\text {th }}$ day, the control fruit

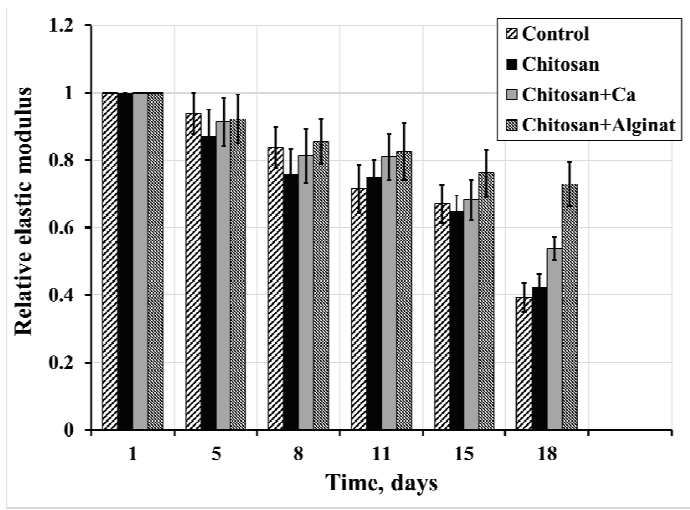

Fig. 5. Mechanical strength of fresh-cut melon cubes during storage at $4{ }^{\circ} \mathrm{C}$

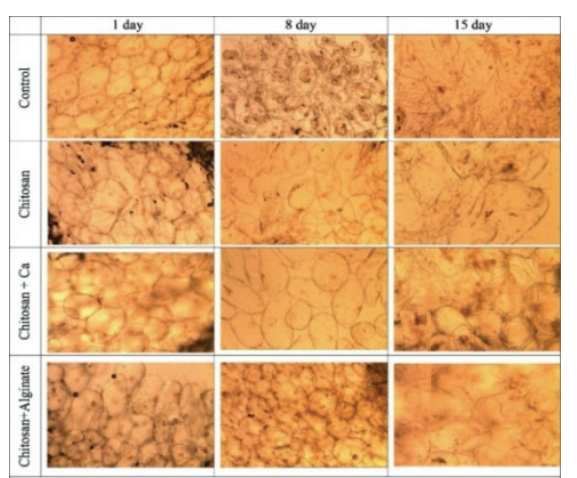

Fig. 6. Micrographs of melon fruit parenchyma tissue during storage at $4{ }^{\circ} \mathrm{C}$ 
showed dehydration and maceration, the cells were separated and isolated, and cell wall was also damaged. The samples coated with pure Ch were soft and its cells were macerated. For the samples, coated with $\mathrm{Ch}+\mathrm{Ca}$ or $\mathrm{Ch}+$ $\mathrm{Al}$ the cell structure was relatively well preserved and the parenchymatous tissue was complete.

After 14 days of storage, structural alterations in the parenchyma tissue were observed for all samples - cell wall damage was more intense, cells were deformed, contracted, and collapsed. Some crystals were accumulated. The most preserved tissues were observed for those samples which were coated with $\mathrm{Ch}+\mathrm{Ca}$ or $\mathrm{Ch}+\mathrm{Al}$. The presence of $\mathrm{Ca}$ bound the cellular pectin kept the cell structure for longer time. The tissue structural changes could be related to higher weight loss during storage (Fig. 1), causing loss of cell turgor pressure.

\section{Statistical analysis}

Based on the statistical analysis (Table 1) of the quality parameters the $\mathrm{Ch}+$ $\mathrm{Al}$ multilayer coating could preserve the fresh values.

Table 1. Results of the statistical analysis for quality parameters $(p=0.05)$

\begin{tabular}{|c|c|c|c|c|c|c|c|c|c|c|c|c|}
\hline & \multicolumn{3}{|c|}{ Control } & \multicolumn{3}{|c|}{ Chitosan } & \multicolumn{3}{|c|}{ Chitosan+Ca } & \multicolumn{3}{|c|}{ Chitosan+Alginat } \\
\hline Day & Avg. \pm Std. & V. & $\mathrm{H}$. & Avg. \pm Std. & V. & H. & Avg. \pm Std. & $\mathrm{V}$. & $\mathrm{H}$. & Avg. \pm Std. & V. & H. \\
\hline \multicolumn{13}{|c|}{ Relative elasticity modulus } \\
\hline 1 & $1.00 \pm 0.00$ & d & $\mathrm{z}$ & $1.00 \pm 0.00$ & e & $\mathrm{z}$ & $1.00 \pm 0.00$ & d & $\mathrm{z}$ & $1.00 \pm 0.00$ & d & $\mathrm{z}$ \\
\hline 5 & $0.94 \pm 0.06$ & d & $\mathrm{z}$ & $0.87 \pm 0.08$ & d & $\mathrm{z}$ & $0.91 \pm 0.07$ & $\mathrm{~cd}$ & $\mathrm{z}$ & $0.92 \pm 0.07$ & $\mathrm{~cd}$ & $\mathrm{z}$ \\
\hline 8 & $0.84 \pm 0.06$ & c & $\mathrm{z}$ & $0.76 \pm 0.07$ & c & $\mathrm{z}$ & $0.81 \pm 0.08$ & c & $\mathrm{z}$ & $0.86 \pm 0.07$ & $\mathrm{bc}$ & $\mathrm{z}$ \\
\hline 11 & $0.72 \pm 0.07$ & $\mathrm{~b}$ & $\mathrm{z}$ & $0.75 \pm 0.05$ & c & $\mathrm{z}$ & $0.81 \pm 0.07$ & c & $\mathrm{z}$ & $0.83 \pm 0.09$ & abc & $\mathrm{z}$ \\
\hline 15 & $0.67 \pm 0.06$ & $\mathrm{~b}$ & zy & $0.65 \pm 0.05$ & $\mathrm{~b}$ & $\mathrm{z}$ & $0.68 \pm 0.06$ & $\mathrm{~b}$ & zy & $0.76 \pm 0.07$ & $a b$ & $\mathrm{y}$ \\
\hline 18 & $0.39 \pm 0.04$ & a & z & $0.42 \pm 0.04$ & a & z & $0.54 \pm 0.03$ & a & $\mathrm{y}$ & $0.73 \pm 0.07$ & $\mathrm{a}$ & $x$ \\
\hline \multicolumn{13}{|c|}{ Weight loss, \% } \\
\hline 1 & $1.06 \pm 0.12$ & a & $\mathrm{z}$ & $0.93 \pm 0.10$ & $\mathrm{a}$ & $\mathrm{z}$ & $0.96 \pm 0.11$ & a & $\mathrm{z}$ & $1.01 \pm 0.13$ & $\mathrm{a}$ & $\mathrm{z}$ \\
\hline 5 & $2.59 \pm 0.31$ & $\mathrm{~b}$ & $\mathrm{z}$ & $2.67 \pm 0.37$ & $\mathrm{~b}$ & $\mathrm{z}$ & $2.60 \pm 0.25$ & $\mathrm{~b}$ & $\mathrm{z}$ & $2.71 \pm 0.30$ & $\mathrm{~b}$ & $\mathrm{z}$ \\
\hline 8 & $5.09 \pm 0.29$ & c & $\mathrm{z}$ & $5.27 \pm 0.41$ & c & $\mathrm{z}$ & $5.49 \pm 0.23$ & c & $\mathrm{z}$ & $5.45 \pm 0.38$ & c & $\mathrm{z}$ \\
\hline 11 & $6.77 \pm 0.47$ & d & z & $6.19 \pm 0.59$ & c & z & $6.75 \pm 0.42$ & d & $\mathrm{z}$ & $7.00 \pm 0.32$ & $\mathrm{~d}$ & $\mathrm{z}$ \\
\hline 15 & $8.64 \pm 0.51$ & e & $\mathrm{z}$ & $7.57 \pm 0.79$ & d & $\mathrm{z}$ & $8.01 \pm 0.60$ & e & $\mathrm{z}$ & $8.64 \pm 0.64$ & e & $\mathrm{z}$ \\
\hline 18 & $8.74 \pm 0.52$ & e & $\mathrm{z}$ & $7.77 \pm 0.80$ & d & $\mathrm{z}$ & $8.50 \pm 0.75$ & e & $\mathrm{z}$ & $8.73 \pm 0.90$ & e & $\mathrm{z}$ \\
\hline
\end{tabular}


Table 1. (Continued)

\begin{tabular}{|c|c|c|c|c|c|c|c|c|c|c|c|c|}
\hline & \multicolumn{3}{|c|}{ Control } & \multicolumn{3}{|c|}{ Chitosan } & \multicolumn{3}{|c|}{ Chitosan+Ca } & \multicolumn{3}{|c|}{ Chitosan+Alginat } \\
\hline Day & Avg. \pm Std. & V. & H. & Avg..tStd. & V. & H. & Avg. \pm Std. & V. & H. & Avg. \pm Std. & V. & H. \\
\hline \multicolumn{13}{|c|}{ Brix, ${ }^{\circ}$} \\
\hline 1 & $9.77 \pm 0.39$ & a & zy & $9.52 \pm 0.40$ & a & $\mathrm{z}$ & $10.27 \pm 0.37$ & $a b$ & $\mathrm{y}$ & $9.87 \pm 0.39$ & a & $\mathrm{zy}$ \\
\hline 5 & $9.80 \pm 0.31$ & a & zy & $9.50 \pm 0.42$ & a & $\mathrm{z}$ & $9.60 \pm 0.31$ & a & $\mathrm{z}$ & $10.30 \pm 0.30$ & a & $\mathrm{y}$ \\
\hline 8 & $10.17 \pm 0.38$ & a & zy & $9.87 \pm 0.39$ & a & $\mathrm{z}$ & $10.87 \pm 0.35$ & bc & $\mathrm{y}$ & $10.52 \pm 0.41$ & a & $\mathrm{z}$ \\
\hline 11 & $12.40 \pm 0.28$ & $\mathrm{~b}$ & $\mathrm{y}$ & $9.87 \pm 0.39$ & a & $\mathrm{z}$ & $11.87 \pm 0.32$ & d & $\mathrm{y}$ & $10.57 \pm 0.44$ & a & $\mathrm{z}$ \\
\hline 15 & $11.94 \pm 0.39$ & $\mathrm{~b}$ & $\mathrm{x}$ & $9.94 \pm 0.47$ & a & $\mathrm{z}$ & $11.44 \pm 0.41$ & $\mathrm{~cd}$ & $\mathrm{yx}$ & $10.94 \pm 0.63$ & $a b$ & $\mathrm{y}$ \\
\hline 18 & $12.27 \pm 0.31$ & $\mathrm{~b}$ & $\mathrm{y}$ & $10.06 \pm 0.43$ & a & $\mathrm{z}$ & $11.61 \pm 0.37$ & d & $\mathrm{y}$ & $12.11 \pm 1.29$ & b & $\mathrm{y}$ \\
\hline \multicolumn{13}{|c|}{ Acidity, g/l } \\
\hline 1 & $0.43 \pm 0.06$ & a & $\mathrm{z}$ & $0.61 \pm 0.06$ & a & $\mathrm{y}$ & $0.47 \pm 0.05$ & a & $\mathrm{z}$ & $0.59 \pm 0.07$ & a & $\mathrm{y}$ \\
\hline 5 & $0.44 \pm 0.02$ & a & $\mathrm{z}$ & $0.61 \pm 0.05$ & a & $\mathrm{y}$ & $0.48 \pm 0.04$ & a & $\mathrm{z}$ & $0.58 \pm 0.06$ & a & $\mathrm{y}$ \\
\hline 8 & $0.44 \pm 0.05$ & a & $\mathrm{z}$ & $0.59 \pm 0.07$ & a & $\mathrm{y}$ & $0.48 \pm 0.05$ & a & $\mathrm{z}$ & $0.59 \pm 0.02$ & a & $\mathrm{y}$ \\
\hline 11 & $0.38 \pm 0.05$ & a & $\mathrm{z}$ & $0.59 \pm 0.05$ & a & $x$ & $0.49 \pm 0.04$ & a & $\mathrm{y}$ & $0.59 \pm 0.04$ & a & $x$ \\
\hline 15 & $0.36 \pm 0.05$ & a & $\mathrm{z}$ & $0.60 \pm 0.06$ & a & $\mathrm{x}$ & $0.45 \pm 0.05$ & a & $\mathrm{y}$ & $0.54 \pm 0.03$ & a & $x$ \\
\hline \multicolumn{13}{|c|}{ Sugar/acid ratio, $1 / \mathrm{g}$} \\
\hline 1 & $230.03 \pm 23.49$ & a & $\mathrm{y}$ & $156.32 \pm 8.32$ & a & $\mathrm{z}$ & $220.09 \pm 14.14$ & $a b$ & $\mathrm{y}$ & $168.39 \pm 12.94$ & a & $\mathrm{z}$ \\
\hline 5 & $223.63 \pm 4.69$ & a & $\mathrm{y}$ & $156.62 \pm 6.01$ & a & $\mathrm{y}$ & $199.68 \pm 11.42$ & a & $\mathrm{x}$ & $177.42 \pm 13.67$ & a & $\mathrm{y}$ \\
\hline 8 & $233.38 \pm 18.83$ & a & $\mathrm{y}$ & $168.36 \pm 12.68$ & a & $\mathrm{z}$ & $226.45 \pm 15.97$ & $\mathrm{~b}$ & $\mathrm{y}$ & $178.44 \pm 10.41$ & a & $\mathrm{z}$ \\
\hline 11 & $333.21 \pm 32.64$ & $\mathrm{~b}$ & $\mathrm{x}$ & $167.88 \pm 8.17$ & a & $\mathrm{z}$ & $245.26 \pm 12.88$ & $\mathrm{bc}$ & $\mathrm{y}$ & $179.40 \pm 13.28$ & a & $\mathrm{z}$ \\
\hline 15 & $336.86 \pm 31.20$ & $\mathrm{~b}$ & $\mathrm{w}$ & $165.35 \pm 7.98$ & a & $\mathrm{z}$ & $255.34 \pm 17.39$ & c & $\mathrm{x}$ & $202.09 \pm 10.25$ & $\mathrm{~b}$ & $\mathrm{y}$ \\
\hline
\end{tabular}

$\mathrm{a}, \mathrm{b}, \mathrm{c}, \mathrm{d}, \mathrm{e}$ or $\mathrm{z}, \mathrm{y}, \mathrm{x}, \mathrm{w}$ : significant difference between the groups vertically and horizontally

This coating showed the smallest changes on the parameters during the storage time. The order in the preservation of the parameters is $\mathrm{Ch}+\mathrm{Al}>$ $\mathrm{Ch}+\mathrm{Ca}>\mathrm{Ch}>$ control. The differences were presented in elasticity modulus, brix, acidity and sugar/acid ratio. These results are in accordance with the results of other authors above for quality parameters (Aday \& Caner, 2010, Baldwin et al., 2011, Martinez-Romero et al., 2006, Poverenov, 2014, Zsom et al., 2016.) 


\section{Microbial analysis}

Microbial analysis of the fresh-cut melons was done based on total aerobic count, yeasts and molds and some pathogens like Salmonella spp., E. coli and Coliforms. Salmonella ssp. was not found in either treated or non-treated samples, while total coliform and E. coli were below the detection limit of the method $\left(<10 \mathrm{CFU} \mathrm{g}{ }^{-1}\right)$. These results indicate that the hygienic practices and the sanitization process were effective (Table 2). Total aerobic counts on the surface of all melon fruit samples (non-treated and coated) steadily increased during storage. The faster growth is observed for non-treated melon cubes and for all days statistical differences were verified. In the presence of $\mathrm{Ch}$ coating alone there was an initial reduction in total counts of about two times (Table 2) within the initial day of the experiment. This difference remained constant during the whole storage time. Statistical difference from the other coatings was present in all measurements. $\mathrm{Ch}+$ $\mathrm{Ca}$ and $\mathrm{Ch}+\mathrm{Al}$ coatings also demonstrated antimicrobial activities, but they ensure less protection than the $\mathrm{Ch}$ alone.

The effects of coatings on mold and yeast growth (Table 2) were similar to the above described for total aerobic counts. No statistical differences were observed between the different coatings and all of them reduced the yeasts and molds two times in comparison with the control samples. The antimicrobial effect of $\mathrm{Ch}$ is well known and has been discussed by many authors, while the mechanisms still cause much controversy.

Table 2. Effect of $\mathrm{Ch}$ based coatings on total aerobic counts $\left(\log \mathrm{CFU} \mathrm{g} \mathrm{g}^{-1}\right)$ and on yeasts and molds $\left(\log \mathrm{CFU} \mathrm{g}{ }^{-1}\right)$ of fresh-cut melons during storage at $4{ }^{\circ} \mathrm{C}(\mathrm{p}=0.05)$

\begin{tabular}{|c|c|c|c|c|c|c|c|c|}
\hline & \multicolumn{2}{|c|}{$1^{\text {st }}$ day } & \multicolumn{2}{c|}{$5^{\text {th }}$ day } & \multicolumn{2}{c|}{$10^{\text {th }}$ day } & \multicolumn{2}{c|}{$15^{\text {th }}$ day } \\
\hline Treatment & Aerobic & Yeast & Aerobic & Yeast & Aerobic & Yeast & Aerobic & Yeast \\
\hline Ch & $220^{\mathrm{a}}$ & $190^{\mathrm{a}}$ & $5400^{\mathrm{a}}$ & $820^{\mathrm{a}}$ & $43666^{\mathrm{a}}$ & $22000^{\mathrm{a}}$ & $1.60 \mathrm{E}+06^{\mathrm{a}}$ & $137000^{\mathrm{a}}$ \\
\hline $\mathrm{ChCa}$ & $290^{\mathrm{b}}$ & $210^{\mathrm{a}}$ & $7100^{\mathrm{ab}}$ & $920^{\mathrm{a}}$ & $58000^{\mathrm{ab}}$ & $24700^{\mathrm{b}}$ & $2.13 \mathrm{E}+06^{\mathrm{b}}$ & $154000^{\mathrm{a}}$ \\
\hline $\mathrm{ChAl}$ & $300^{\mathrm{b}}$ & $215^{\mathrm{a}}$ & $7333^{\mathrm{b}}$ & $950^{\mathrm{a}}$ & $59666^{\mathrm{b}}$ & $25300^{\mathrm{b}}$ & $2.20 \mathrm{E}+06^{\mathrm{b}}$ & $158000^{\mathrm{a}}$ \\
\hline Control & $470^{\mathrm{c}}$ & $340^{\mathrm{b}}$ & $11666^{\mathrm{c}}$ & $1500^{\mathrm{b}}$ & $95033^{\mathrm{c}}$ & $40000^{\mathrm{c}}$ & $3.50 \mathrm{E}+06^{\mathrm{c}}$ & $250000^{\mathrm{b}}$ \\
\hline
\end{tabular}

a,b,c: significant difference between the groups

The polycationic property of chitosan may interfere with the negatively charged residues of macromolecules at the surface. Also Ch interacts with the membrane of the cell to alter cell permeability. The other mechanism 
involves the binding of chitosan with DNA to inhibit RNA synthesis (Fei Liu et al., 2001). Based on our results one could assume that the addition of $\mathrm{Ca}$ and $\mathrm{Al}$ did not significantly affect the antibacterial properties of $\mathrm{Ch}$ coatings.

\section{Conclusion}

In the present study the effect of different $\mathrm{Ch}$ based edible coatings on the postharvest parameters of fresh-cut melon fruits were investigated. It was demonstrated that low molecular weight $\mathrm{Ch}$ coatings improve all the investigated parameters. The addition of $\mathrm{Ca}$ and $\mathrm{Al}$ showed beneficial effect on weight loss, Brix, TA and texture of the melons and preserved the cellular structure of the parenchyma tissue of the melon fruit. The bacteriostatic activity of $\mathrm{Ch}$ decreased, but the coatings still can supply antibacterial protection against bacteria, yeasts and molds.

\section{References}

Aday, M. S. \& C. Caner (2010). Understanding the effects of various edible coatings on the storability of fresh cherry. Packaging Technology and Science, 23, 441-456.

Baldwin, E. A., Hagenmaier, R. \& Bai, J. (2011). Edible coatings and films to improve food quality (2nd ed.). Boca Raton: CRC.

Chong, J. X., Shaojuan, L. \& Hongshun, Y. (2015). Chitosan combined with calcium chloride impacts fresh-cut honeydew melon by stabilising nanostructures of sodium-carbonate-soluble pectin. Food Control, 53, 195-205.

Coma, V., Martial Gros, A., Garreau, S., Copinet, A., Salin, F., \& Deschamps, A. (2002). Edible antimicrobial films based on chitosan matrix. J. of Food Science, 67(3), 11621169.

Cook, R. (2014). Trends in the marketing of fresh produce and freshcut products. University of California Davis, USA.

Dutta, P. K., Tripathi, S., Mehrotra, G. K. \& Dutta, J. (2009). Perspectives for chitosan based antimicrobial films in food applications. Food Chemistry, 114(4), 1173-1182.

Fei Liu, X., Lin Guan, Y., Zhi Yang, D., Li, Z. \& De Yao, K. (2001). Antibacterial action of chitosan and carboxymethylated chitosan. Journal of Applied Polymer Science, 79(7), 1324-1335.

Han, J. H. \& Gennadios, A. (2005). Edible films and coatings. A review. In: Innovations in food packaging (edited by Han, J. H.), chapter 15 (pp. 239-262). Amsterdam: Elsevier Academic.

Martínez-Romero, D., Alburquerque, N., Valverde, J. M., Guillén, F., Castillo, S., Valero, D. \& Serrano, M. (2006). Postharvest sweet cherry quality and safety maintenance by Aloe vera treatment: a new edible coating. Postharvest Biology and Technology, 39(1), 93-100. 
OECD Standards (2005). Guidance on Objective Tests to Determine Quality of Fruits and Vegetables and Dry and Dried Produce, OECD Brochures 2005, pp. 11-15.

Olivas, G. I. \& Barbosa-Cánovas, G. V. (2005). Edible coatings for fresh-cut fruits. Critical Reviews in Food Science and Nutrition, 45, 657-670.

Poverenov, E., Danino, S., Horev, B., Granit, R., Vinokur, Y. \& Rodov, V. (2014). Layerby-layer electrostatic deposition of edible coating on fresh cut melon model: Anticipated and unexpected effects of alginate-chitosan combination. Food and Bioprocess Technology, 7(5), 1424-1432.

Qi, H., Hu, W., Jiang, A., Tian, M. \& Li, Y. (2011). Extending shelf-life of fresh-cut 'Fuji' apples with chitosan-coatings. Innovative Food Science \& Emerging Technologies, 12(1), 62-66.

Raybaudi-Massilia, Rosa M., Mosqueda-Melgar, J. \& Martín-Belloso, O. (2008). Edible alginate-based coating as carrier of antimicrobials to improve shelf-life and safety of fresh-cut melon. International Journal of Food Microbiology, 121, 313-327.

Soliva-Fortuny, R. C. \& Martín-Belloso, O. (2003). New advances in extending the shelflife of fresh-cut fruits: a review. Trends in Food Science \& Technology, 14, 341-353.

Tapia, C., Escobar, Z., Costa, E., Sapag-Hagar, J., Valenzuela, F., Basualto, C., ... \& Yazdani-Pedram, M. (2004). Comparative studies on polyelectrolyte complexes and mixtures of chitosan-alginate and chitosan-carrageenan as prolonged diltiazem clorhydrate release systems. European Journal of Pharmaceutics and Biopharmaceutics, 57(1), 65-75.

Zsom, T., Zsom-Muha, V., Dénes, D. L., Baranyai, L. \& Felföldi, J. (2016). Quality changes of pear during shelflife. Progress in Agricultural Engineering Sciences, 12(1), 81-106. 